1 Taras Shevchenko National University of Kyiv

(4, Academician Glushkov Ave., Kyiv 03022, Ukraine; e-mail: alyona_kizima@mail.ru)

2 Joint Institute for Nuclear Research

(6, Joliot-Curie Str., Dubna 141980, Russian Federation)

\title{
LIQUID SYSTEMS WITH FULLERENES IN ORGANIC SOLVENTS AND AQUEOUS MEDIA ${ }^{1}$
}

\begin{abstract}
The unique properties of nanocarbon materials - in particular, fullerenes - has led in recent years to the expansion of the spectrum of their application in various fields of the industry, including the chemical, energy, and pharmaceutical ones. The use of fullerenes in new industries poses new challenges to the scientific and research community. Thus, new methods of obtaining biocompatible liquid systems with small-sized monodisperse fullerene aggregates are still being sought. The paper focuses on the properties of fullerene solutions in mixtures of organic solvents, which serve as a basis for the development of new methods for synthesizing the aqueous liquid systems with fullerenes.

Keywords: fullerene solutions, solvatochromic effect, aggregation, toxicity.
\end{abstract}

\section{Introduction}

The discovery of fullerenes - a new allotropic form of carbon, the third one after graphite and diamond was a decisive step in the development of modern nanotechnology. The study of the structure and the properties of fullerenes gave the main impetus for the development of the physics and chemistry of nanocarbon systems such as nanotubes, graphene, nanodiamonds, endofullerenes, and others. Due to their symmetric structure and small size (about $1 \mathrm{~nm}$ ), fullerenes possess unique properties, which led to a wide spectrum of their application in modern technologies $[1,2]$, in particular, in medicine [3-6]. First of all, it occurs, because fullerenes are the first soluble form of carbon. The studies of their solutions and mixtures became widespread, and interest to them does not decrease till now [7-9].

The solubility of fullerenes is associated with their structure [10], which strongly resembles the structure of many organic solvents. Another substantial factor is a weak intermolecular bond in fullerene crystallites, unlike that in graphite and diamond. Currently, there is no generalized parameter which could be used to evaluate the solubility of fullerenes in that or another solvent $[8,11,12]$. However, the solvent polarity should be regarded as the main factor affecting the

(C) O.A. KYZYMA, 2020

ISSN 2071-0194. Ukr. J. Phys. 2020. Vol. 65, No. 9 solubility of fullerenes. For instance, fullerenes were found to be highly soluble (more than $1 \mathrm{mg} / \mathrm{ml}$ ) in non-polar solvents and almost insoluble in polar ones, in particular, in water $[10,13]$. This fact stimulated a number of studies aimed at embedding fullerene molecules into an aquatic environment.

Today, the most common methods for obtaining aqueous liquid systems of fullerenes are as follows: the modification of the fullerene surface with functional groups such as hydroxyl and carboxyl ones [14-16], solvent-exchange method (with organic solvents being used at the first stage) $[17,18]$, surface solubilization with surfactants or polymers $[19,20]$, and even a direct dispersion of fullerenes in water [21]. However, if the surface of fullerenes does not undergo a strong modification, none of those techniques makes it possible to produce liquid systems with fullerene monomers. Therefore, despite a variety of available methods, the problem of fullerene stabilization in an aqueous medium still remains unsolved.

The challenging character of this problem is associated, first of all, with the requirements to liquid systems that are promising for medical and biological applications. It is so, because the interaction of cell membranes with nanoparticles and their associates,

1 This article is dedicated to the 75th anniversary of Academician L.A. Bulavin. 
as well as the binding and activation of membrane receptors, is known to depend on the nanoparticle size [22-24]. Therefore, the search for new and improved methods for synthesizing the aqueous liquid systems with fullerenes is still being continued in order to produce systems with small aggregates characterized by a low size polydispersity.

Among the solvents of fullerenes, solvents with electronegative atoms such as oxygen or nitrogen, and five- or six-membered heterocycles in their composition should be included in a separate group. The presence of such heterocycles in the structure of solvent molecules results in a relatively high solubility of fullerenes - e.g., $0.98 \mathrm{mg} / \mathrm{ml}$ for pyridine and $0.99 \mathrm{mg} / \mathrm{ml}$ for N-methylpyrrolidone [10] - even at the dielectric constants of 12.3 and 32 , for those solvents, respectively. The combination of the high polarity of those solvents, which provides their miscibility with water, and the high solubility of fullerenes in them attracted special attention to their research. This paper deals with the properties of the indicated systems, which are considered as potential co-solvents for transposing fullerenes into water, and aqueous liquid systems obtained on their basis.

\section{Properties of Fullerene Solutions in the Mixtures of Organic Solvents}

The second half of the 1990s was devoted to the research of the properties of liquid systems with fullerenes. The aggregation processes and their dependence on the fullerene concentration [25-29] and the polarity of solvent mixtures [30-36] were intensively studied at that time. In particular, the origins of solvatochromic effects in the mixtures of solvents with fullerenes were determined [37,38], and the method of solvent exchange was invented $[17,39]$. It allowed aqueous liquid systems with fullerenes, but without a chemical modification of their surface, to be obtained.

A critical value of the dielectric constant of the mixture, at which the aggregation of fullerene molecules arises, was determined $[11,30,31]$. The tendency to the aggregation was observed, as the fullerene concentration increases, which is directly connected with the saturation concentration of fullerenes in a particular solvent [25-29]. The both cases of aggregation are responsible for the appearance of the inverse solvatochromic effect in the optical absorption spectra, which was observed for a number of polar/nonpolar solvent mixtures.
Among other works, the work by Mrzel et al. [40] deserves special attention. It was devoted to the study of the relation between the clustering and the solvatochromism of the liquid system $\mathrm{C}_{60}$ in a pyridine-water mixture. The unique character of this work consisted in the application of a mixture of two polar solvents, in contrast to the previous works, where the examined mixture was usually composed of a polar and a nonpolar solvent. As a result, the inverse solvatochromism was revealed, which was accompanied by the formation of aggregates with size about $30 \mathrm{~nm}$. The aggregates were surrounded by a pyridine shell that performed the stabilizing functions. The results showed that pyridine can be used as an initial solvent that stabilizes fullerene aggregates in water.

However, pyridine is a toxic solvent. The results of experiments on the toxicity of liquid systems with fullerenes [41-44], which were obtained using the solvent exchange method, testified to a significant effect of the toxicity of the initial solvent on the ultimate properties of the system. Therefore, it was necessary to find a solvent with a lower toxicity, which could be used as a co-solvent in drugs. As such a solvent, Nmethylpyrrolidone (NMP) was found. It has dielectric constant of 32 , it is completely miscible with water, and it is characterized by a sufficiently high solubility of fullerene in it.

The studies of the liquid system $\mathrm{C}_{60}$ and $\mathrm{C}_{70}$ in NMP also revealed the temporal solvatochromic effect. The latter manifested itself as a decrease in the intensity of characteristic fullerene peaks in the absorption spectrum and a transition to its smooth profile within a spectral interval of $300-500 \mathrm{~nm}$. This phenomenon could be associated with several mechanisms, including the complex formation and aggregation, which give rise to the growth of the Mie scattering contribution to the optical absorption spectrum. Using the method of dynamic light scattering, it was shown that an increase of the fullerene aggregates was observed in the $\mathrm{C}_{60} / \mathrm{NMP}$ system, and the aggregate size exceeded $100 \mathrm{~nm}$ within a month after the solution preparation [45-47]. However, the contribution of the Mie scattering to the optical absorption spectrum of the system was found to be not substantial [48].

Later, a similar solvatochromic effect, i.e. the transformation of the absorption spectrum to a smooth form in time, was also revealed in fullerene

ISSN 2071-0194. Ukr. J. Phys. 2020. Vol. 65, No. 9 
solutions in the NMP/toluene [49] and NMP/water [50] mixtures. Unlike the solvatochromic effects detected in the fullerene solutions in the previously studied benzene-benzonitrile [30], toluene-acetonitrile $[10,11,51]$, benzene-methanol, and dichlorobenzeneacetonitrile [52] mixtures, the solvatochromic effect in the case of liquid systems with NMP in their compositions was not inverse, i.e. the increase of the water or toluene content in the system with a completely smooth absorption spectrum did not lead to characteristic changes in the latter [53]. This fact testified to a different origin of the solvatochromic effect.

Besides the time-dependent solvatochromic effect, the studies of the $\mathrm{C}_{60} / \mathrm{NMP} /$ water and $\mathrm{C}_{70} / \mathrm{NMP} /$ toluene systems $[54,55]$ also revealed the drastic appearance of the solvatochromism when adding second solvent to the initial $\mathrm{C}_{60} / \mathrm{NMP}$ system, the absorption spectrum of which had not been ultimately smoothed out yet [56]. It was shown that the both effects emerge owing to the formation of donor-acceptor bonds [50,57], which, according to the results of theoretical calculations, are formed between oxygen atoms in the NMP molecule and carbon atoms of fullerene $[58,59]$. The formation of donor-acceptor bonds is responsible for the aggregate stabilization and changes the fullerene properties. In particular, fullerenes sedimented from NMP are not dissolved in toluene, and, according to the dynamic light scattering data, the addition of water to the $\mathrm{C}_{60} / \mathrm{NMP}$ system gives rise to the destruction of fullerene aggregates (Fig. 1) [60]. Later, using the small-angle neutron scattering method, it was found that the destruction of aggregates depends on the water content [61]. Furthermore, according to results of the extraction method and the mass spectrometry data, the destruction was found to occur owing to the detachment of fullerene monomers from the aggregate surface (Fig. 1) [62, 63]. In effect, the dissolution of fullerene-NMP complexes in an aqueous medium was observed.

The processes of growth and decay of aggregates, when water is added to the system, were theoretically considered in works [46,64-66]. It was found that if the initial $\mathrm{C}_{60} / \mathrm{NMP}$ system was diluted with water, the final size of fullerene aggregates depended on their size in the initial $\mathrm{C}_{60} / \mathrm{NMP}$ system [67], where the growth of aggregates to about $500 \mathrm{~nm}$ took about a month [45-47]. This unique property made the size of aggregates in the final aqueous liquid system to be

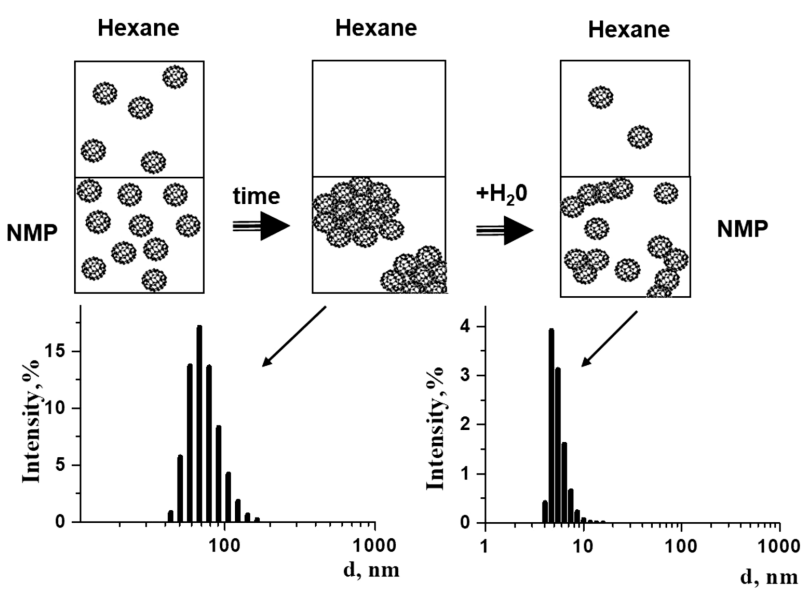

Fig. 1. (upper panel) Schematic diagram of the experiment on extraction of fullerenes from a liquid $\mathrm{C}_{60} / \mathrm{NMP}$ system in hexane: by holding the system for some time and by diluting the $\mathrm{C}_{60} / \mathrm{NMP}$ system with water. (lower panel) Dynamic light scattering spectra of the $\mathrm{C}_{60} / \mathrm{NMP}$ system obtained 3 weeks after its preparation (left) and after adding water to this system (right)

controllable in the course of their synthesis. As a result, the aqueous liquid systems with characteristic aggregate sizes of about $8 \mathrm{~nm}$ were obtained. However, the method applied for the synthesis of such systems has an obvious shortcoming: this is the presence of the initial solvent in the final liquid system.

\section{Toxicity of Aqueous Liquid Systems with Fullerenes: Main Aspects}

In the early 2000s, laboratories around the world focused their attention on the toxicity of aqueous liquid systems with fullerenes. The solvent exchange method proposed by G.V. Andrievsky [17] was regarded to be the most promising for their synthesis. It allowed a number of organic solvents immiscible with water to be used as initial solvents. For this purpose, toluene [68,69], tetrahydrofuran [70-75], and benzene [76] were used most often. The results of studies of the toxicity of indicated liquid systems were mutually contradicting, which invoked discussions about the prospects of those systems for further medical and biological applications. Later, there were proposed several factors that might affect the results of toxicity experiments. The most wide-spread were the following ones: the size of aggregates, the remnants of the initial organic solvent, and the choice of the biological object to study. 

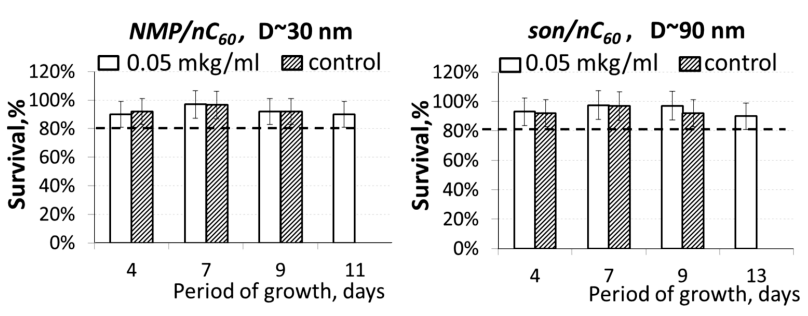

Fig. 2. Survival of Chinese hamster fibroblast cells of the $\mathrm{V}$-79 line during 13 days in the presence of aqueous fluid systems with fullerenes, $\mathrm{NMP} / \mathrm{nC}_{60}$ and son $/ \mathrm{nC}_{60}$, with different aggregate sizes. The $\mathrm{C}_{60}$ concentration is $0.05 \mu \mathrm{g} / \mathrm{ml}$

The lack of a detailed analysis of the structure of aqueous liquid systems with fullerenes - in particular, the size and morphology of aggregates - and a necessity to analyze the influence of the physiological environment on the structure of fullerene aggregates [77] considerably restricted the solution of this problem. Another problem consisted in that the aqueous systems produced using the solvent exchange methods were characterized by a substantial size polydispersity, with the average aggregate size being of about $70-90 \mathrm{~nm}$. It also restricted the capability to analyze the influence of the fullerene aggregate size on the toxicity.

Later, there appeared works in which of the centrifugation was used to produce aqueous liquid systems with micro- and nanometer-sized fullerene aggregates $[78,79]$, and the toxicity of the latter was higher. With the advent of $\mathrm{NMP} / \mathrm{nC}_{60}$ and $\mathrm{NMP} / \mathrm{nC}_{70}$ aqueous systems, in which the aggregate sizes were almost three times as small, it was shown that the nanometer-sized fullerene aggregates do not affect the system toxicity (Fig. 2) [80,81].

On the other hand, to analyze the influence of initial-solvent remnants on of the toxicity, experiments were carried out in which the toxicity of aqueous liquid systems with fullerenes obtained using various initial organic solvents was compared. The systems prepared making use of tetrahydrofuran (THF) were found to be more toxic [74]. It was supposed that the molecules of the tetrahydrofuran solvent remain bound in the $\mathrm{nC}_{60}$ aggregates, which is responsible for the toxic effect of the latter. It was also predicted that the formation of the fullerene-THF complex may have a synergistic toxic effect [82]. In 2017, Yang et al. [83] showed that the application of THF in the solvent exchange method leads to the destruction of the fullerene core. Just this action can be the cause of the increased toxicity of such systems in comparison with the aqueous solutions obtained following the same method, but using toluene.

Therefore, one cannot underestimate the influence of initial solvent on the biological properties of the systems concerned. That is why the method of synthesis of aqueous liquid systems using NMP was later improved with the help of the dialysis method [84]. The latter minimizes the amount of the initial solvent in the final aqueous system. This aqueous liquid system turned out effective for inhibiting the herpes virus and cytomegalovirus infection [85]. The anti-inflammatory effect was also demonstrated in the case of the mice model of atopic dermatitis [86]. Thus, systematic studies of the liquid systems with fullerenes comprise an important step in understanding the capabilities of those systems. They open new areas of their application in various fields of modern technology, including medicine.

\section{Conclusions}

To summarize, the main properties of the liquid systems with fullerenes in the mixtures of organic solvents have been considered. The contributions of colloidal aspects and the complex formation to solvatochromic effects are discussed. The main factors affecting the results of experiments aimed at the study of the toxicity of aqueous liquid systems are analyzed. Among other factors, a substantial role of the initial solvent choice in the biocompatibility of the final aqueous fullerene systems was revealed.

The authoress is sincerely grateful to Academician of the NAS of Ukraine L.A. Bulavin and to the staff of the Laboratories of Neutron Physics and Radiation Biology of the Joint Institute for Nuclear Research for fruitful discussions.

1. M.S. Dresselhaus, G. Dresslhaus. Fullerenes and fullerene derived solids as electronic materials. Annu. Rev. Mater. Sci. 25, 487 (1995).

2. J. Coro, M. Suarez, L.S.R. Silva et al. Fullerene applications in fuel cells: A review. Annu. Rev. Mater. Sci. 41, 17944 (2016).

3. E. Castro, A. Hernandez Garcia, G. Zavala, L. Echegoyen. Fullerenes in biology and medicine. J. Mater. Chem. B 5, 6523 (2017).

4. U. Ritter, P. Scharff, Yu.I. Prylutskyy, V. Cherepanov, A. Senenko, O. Kyzyma, O. Litsis, A. Naumovets. Synthesis and characteristics of $\mathrm{C}_{60}$ fullerene aqueous colloid. In: Multifunctional Nanomaterials for Biology and Medicine: 
Molecular Design, Synthesis and Application. Edited by R.S. Stoika (Naukova Dumka, 2017), p. 84.

5. L.A. Bulavin, Y. Prylutskyy, O. Kyzyma et al. Self-organization of pristine $\mathrm{C}_{60}$ fullerene and its complexes with chemotherapy drugs in aqueous solution as promising anticancer agents. In: Modern Problems of Molecular Physics. Edited by L. Bulavin, A. Chalyi (Springer, 2018), p. 3.

6. O. Kyzyma, N. Bashmakova, Yu. Gorshkova et al. Interaction between the plant alkaloid berberine and fullerene $\mathrm{C}_{70}$ : Experimental and quantum-chemical study. J. Mol. Liq. 278, 452 (2019).

7. S. Goodarzi, T. Da Ros, J. Conde et al. Fullerene: Biomedical engineers get to revisit an old friend. Mater. Today 20, 460 (2017).

8. N.O. Mchedlov-Petrossyan. Fullerenes in liquid media: an unsettling intrusion into the solution chemistry. Chem. Rev. 113, 5149 (2013).

9. O.A. Kyzyma, A.V. Tomchuk, M.V. Avdeev et al. Structural researches of carbonic fluid nanosystems. Ukr. J. Phys. 60, 835 (2015).

10. V.N. Bezmel'nitsyn, A.V. Eletskii, M.V. Okun'. Fullerenes in solutions. Ukr. J. Phys. 41, 1091 (1998).

11. N.O. Mchedlov-Petrossyan, N.N. Kamneva, Y.T.M. AlShuuchi et al. The peculiar behavior of fullerene $\mathrm{C}_{60}$ in mixtures of "good" and polar solvents: Colloidal particles in the toluene-methanol mixtures and some other systems. Colloid. Surf. A 509, 631 (2016).

12. N.O. Mchedlov-Petrossyan. Fullerenes in aqueous media: A review. Theor. Exper. Chem. 55, 361 (2020).

13. M.V. Korobov, A.L. Mirakian, N.V. Avramenko et al. $\mathrm{C}_{60}$. Bromobenzene solvate: Crystallographic and thermochemical studies and their relationship to $\mathrm{C}_{60}$ solubility in bromobenzene. J. Phys. Chem. B 102, 3712 (1998).

14. K. Kokubo, K. Matsubayashi, H. Tategaki, H. Takada, T. Oshima. Facile synthesis of highly water-soluble fullerenes more than half-covered by hydroxyl groups. ACS Nano 2, 327(2008).

15. A. Djordjevic, J.M. Canadanovic-Brunet, M. VojinovicMiloradov, G. Bogdanovic. Antioxidant properties and hypothetic radical mechanism of fullerenol $\mathrm{C}_{60}(\mathrm{OH})_{24}$. Oxid. Commun. 27, 30 (2020).

16. V.T. Lebedev, Yu.V. Kulvelis, A.S. Voronin, A.V. Komolkin, E.A. Kyzyma, T.V. Tropin, V.M. Garamus. Mechanisms of supramolecular ordering of water-soluble derivatives of fullerenes in aqueous media. Fulleren. Nanotub. Carbon Nanostruct. 28, 30 (2020).

17. G.V. Andrievsky, M.V. Kosevich, O.M. Vovk et al. On the production of an aqueous colloidal solution of fullerenes. J. Chem. Soc. Chem. Commun. 12, 1281 (1995).

18. M.V. Avdeev, A.A. Khokhryakov, T.V. Tropin et al. Colloidal solutions of $\mathrm{C}_{60}$ fullerenes in water by small-angle neutron scattering. Langmuir 20, 4363 (2004).

19. D.M. Guld. Capped fullerenes: Stabilization of watersoluble fullerene monomers as studied by flash photolysis and pulse radiolysis. J. Phys. Chem. A 101, 3895 (1997).

20. T. Andersson, K. Nilsson, M. Sundahl, G. Westman, O. Wennerström. $\mathrm{C}_{60}$ embedded in $\gamma$-cyclodextrin: A wa- ter-soluble fullerene. J. Chem. Soc. Chem. Commun. 8, 604 (1992).

21. C. Isaacson, W. Zhang, T. Powell, X. Ma, D. Bouchard. Temporal changes in aqu/ $\mathrm{C}_{60}$ physical-chemical, deposition, and transport characteristics in aqueous systems. Sci. Technol. 45l, 5170 (2011).

22. W. Jiang, B.Y.S. Kim, Y.T. Rutka, W.C.W. Chan. Nanoparticle mediated cellular response is size-dependent. Nat. Nanotechnol. 3, 145 (2008).

23. E.M. Hotze, J.Y. Bottero, M.R. Wiesner. Theoretical framework for nanoparticle reactivity as a function of aggregation state. Langmuir 26, 11170 (2010).

24. Y. Ha, L.E. Katz, H.M. Liljestrand. Distribution of fullerene nanoparticles between water and solid supported lipid membranes: thermodynamics and effects of membrane composition on distribution. Environ. Sci. Technol. 49, 14546 (2015).

25. F. Migliardo, V. Magazu, M. Migliardo. Structural properties of $\mathrm{C}_{60}$ in solution. J. Mol. Liq 110, 3 (2004).

26. S. Nath, H. Pal, D. Palit, A. Sapre and J. Mittal. Aggregation of fullerene, $\mathrm{C}_{60}$, in benzonitrile. J. Phys. Chem. B 102, 10158 (1998).

27. R.G. Alargova, S. Deguchi, K. Tsujii. Stable colloidal dispersions of fullerenes in polar organic solvents. J. Am. Chem. Soc. 123, 10460 (2001).

28. M.V. Avdeev, T.V. Tropin, I.A. Bodnarchuk et al. On structural features of fullerene $\mathrm{C}_{60}$ dissolved in carbon disulfide: Complementary study by small-angle neutron scattering and molecular dynamic simulations. J. Chem. Phys. 132, 164515 (2010)

29. D. Alok, B. Patnaik, A. Patnaik. Microscopic diffusion model applied to $\mathrm{C}_{60}$ fullerene fractals in carbondisulphide solution. J. Chem. Phys. 119, 4529 (2003).

30. S. Nath, H. Pal, A.V. Sapre. Effect of solvent polarity on the aggregation of $\mathrm{C}_{60}$. Chem. Phys. Lett. 327, 143 (2000).

31. S. Nath, H. Pal, A.V. Sapre. Effect of solvent polarity on the aggregation of fullerenes: A comparison between $\mathrm{C}_{60}$ and $\mathrm{C}_{70}$. Chem. Phys. Lett. 360, 422 (2002).

32. N.O. Mchedlov-Petrossyan, N.N. Kamneva, Y.T.M. AlShuuchi, A.I. Marynin, O.S. Zozulia. The peculiar behaviors of fullerene $\mathrm{C}_{60}$ in mixtures of "good" and polar solvents: Colloidal particles in the toluene-methanol mixtures and some other systems. J. Mol. Liq. 235, 98 (2017).

33. M. Alfè, B. Apicella, R. Barbella, A. Bruno and A. Ciajolo. Aggregation and interactions of $\mathrm{C}_{60}$ and $\mathrm{C}_{70}$ fullerenes in neat $\mathrm{N}$-methylpyrrolidinone and in N-methylpyrrolidinone/toluene mixtures. Chem. Phys. Lett. l 405, 193 (2005).

34. M.V. Avdeev, V.L. Aksenov, T.V. Tropin. Models of cluster formation in solutions of fullerenes. Russ. J. Phys. Chem. 84, 1273 (2010).

35. N.O. Mchedlov-Petrossyan, N.N. Kamneva, Y.T.M. AlShuuchi, A.I. Marynin, O.S. Zozulia, A.P. Kryshtal, V.K. Klochkov, S.V. Shekhovtsov. Towards better understanding of $\mathrm{C}_{60}$ organosols. Phys. Chem. Chem. Phys. 18, 2517 (2016).

36. I.V. Mikheev, E.S. Khimich, A.T. Rebrikova, D.S. Volkov, M.A. Proskurnin, M.V. Korobov. Quasi-equilibrium distri- 
bution of pristine fullerenes $\mathrm{C}_{60}$ and $\mathrm{C}_{70}$ in a water-toluene system. Carbon 111, 191 (2017).

37. T.V. Nagorna, M.O. Kuzmenko, O.A. Kyzyma, D. Chudoba, A.V. Nagornyi, T.V. Tropin, V.M. Garamus, M. Jazdzewska, L.A. Bulavin. Structural reorganization of fullerene $\mathrm{C}_{70}$ in N-methyl-2-pyrrolidone/toluene mixtures. J. Mol. Liq. 272, 948 (2018).

38. L.A. Bulavin, T.V. Nagorna, D. Chudoba, O.A. Kyzyma, O.I. Ivankov. Small-angle neutron scattering by liquid systems of fullerenes $\mathrm{C}_{60}$ and $\mathrm{C}_{70}$. Yad. Fiz. Energ. 19, 252 (2018) (in Ukrainian).

39. I.V. Mikheev, I.E. Kareev, V.P. Bubnov, D.S. Volkov, M.V. Korobov, M.A. Proskurnin. Development of standard reference samples of aqueous fullerene dispersions. J. Anal. Chem. 73, 837 (2018).

40. A. Mrzel, A. Mertelj, A. Omerzu, M. Copia, D. Mihailovic. Investigation of encapsulation and solvatochromism of fullerenes in binary solvent mixtures. J. Phys. Chem. B. 103, 11256 (1999).

41. A. Dhawan, J.S. Taurozzi, A.K. Pandey, W. Shan, S.M. Miller, S.A. Hashsham, V.V. Tarabara. Stable colloidal dispersions of $\mathrm{C}_{60}$ fullerenes in water: Evidence for genotoxicity. Environ. Sci. Technol. 40, 7394 (2006).

42. S.V. Prylutska, I.I. Grynyuk, O.P. Matyshevska, Yu.I. Prylutskyy, U. Ritter, P. Scharff. Anti-oxidant properties of $\mathrm{C}_{60}$ fullerenes in vitro. Fulleren. Nanotub. Carbon Nanostruct. 42, 698 (2008).

43. A.H. Ringwood, N. Levi-Polyachenko, D.L. Carroll. Fullerene exposures with oysters: Embryonic, adult, and cellular responses. Environ. Sci. Technol. 43, 7136 (2009).

44. T. Mori, H. Takada, S. Ito, K. Matsubayashi, N. Miwa, T. Sawaguchi. Preclinical studies on safety of fullerene upon acute oral administration and evaluation for no mutagenesis. Toxicology 225, 48 (2006).

45. T.V. Tropin, N. Jargalan, M.V. Avdeev, O.A. Kyzyma, D. Sangaa, V.L. Aksenov. The calculation of cluster size distribution functions and SANS data for $\mathrm{C}_{60} / \mathrm{NMP}$ solution. Phys. Solid State 56, 148 (2014).

46. T.V. Tropin, N. Jargalan, M.V. Avdeev, O.A. Kyzyma, R.A. Eremin, D. Sangaa, V.L. Aksenov. Kinetics of cluster growth in polar solutions of fullerene: Experimental and theoretical study of $\mathrm{C}_{60} / \mathrm{NMP}$ solution. J. Mol. Liq. 175, 4 (2012).

47. T.V. Tropin, M.V. Avdeev, O.A. Kyzyma, V.L. Aksenov. Nucleation theory models for describing kinetics of cluster growth in $\mathrm{C}_{60}$ /NMP solutions. Phys. Status Solidi B 247, $3022(2010)$.

48. O.A. Kyzyma, L.A. Bulavin, V.L. Aksenov, M.V. Avdeev, T.V. Tropin, M.V. Korobov, S.V. Snegir, L. Rosta. Organization of fullerene clusters in the system $\mathrm{C}_{60} / \mathrm{N}$-metyl-2pyrrolidone. Mater. Struct. 15, 17 (2008).

49. T.V. Nagorna, O.A. Kyzyma, L.A. Bulavin et al. Specifics of $\mathrm{C}_{60}$ fullerene cluster formation in a solvent mixture of toluene and N-methyl-2-pyrollidone. J. Synch. Investig. 12, 872 (2018).

50. T.V. Tropin, T.O. Kyrey, O.A. Kyzyma, A.V. Feoktistov, M.V. Avdeev, L.A. Bulavin, L. Rosta, V.L. Aksenov. Ex- perimental investigation of $\mathrm{C}_{60} / \mathrm{NMP}$ / toluene solutions by UV-Vis spectroscopy and small-angle neutron scattering. J. Synch. Investig. 7, 1 (2013).

51. Y.P. Sun, C.E. Bunker. $\mathrm{C}_{70}$ in solvent mixtures. Nature 36, 398 (1993).

52. H.N. Ghosh, A.V. Sapre, J.P. Mittal. Aggregation of $\mathrm{C}_{70}$ in solvent mixtures. J. Phys. Chem. 100, 9439 (1996).

53. O.A. Kyzyma, T.O. Kyrey, M.V. Avdeev, M.V. Korobov, L.A. Bulavin, V.L. Aksenov. Non-reversible solvatochromism in N-methyl-2-pyrrolidone/toluene mixed solutions of fullerene $\mathrm{C}_{60}$. Chem. Phys. Lett. 556, 178 (2013).

54. T.V. Nagorna, O.A. Kyzyma, D. Chudoba, A.V. Nagornyi. Temporal solvatochromic effect in ternary $\mathrm{C}_{70} /$ toluene/ $\mathrm{N}$ methyl-2-pyrrolidone solution. J. Mol. Liq. 235, 111 (2017).

55. O.A. Kyzyma, M.V. Korobov, M.V. Avdeev, V.M. Garamus, V.I. Petrenko, V.L. Aksenov, L.A. Bulavin. Solvatochromism and fullerene cluster formation in $\mathrm{C}_{60} / \mathrm{N}-\mathrm{me}-$ thyl-2-pyrrolidone. Fulleren. Nanotub. Carbon Nanostruct. 18, 458 (2010).

56. T.O. Kyrey, O.A. Kyzyma, M.V. Avdeev,T.V. Tropin, M.V. Korobov, V.L. Aksenov, L.A. Bulavin. Absorption characteristics of fullerene $\mathrm{C}_{60}$ in N-methyl-2-pirrolidone/toluene mixture. Fulleren. Nanotub. Carbon Nanostruct. 20, 341 (2010).

57. L.A. Bulavin, T.V. Nagorna, O.A. Kyzyma, D. Chudoba, O.I. Ivankov, A.V. Nagornyi, M.V. Avdeev. Fullerene clustering in $\mathrm{C}_{70} / \mathrm{N}$-methyl-2-pyrrolidone/toluene liquid system. Ukr. J. Phys. 63, 116 (2018).

58. S.V. Snegir, T.V. Tropin, O.A. Kyzyma, M.O. Kuzmenko, V.I. Petrenko, V.M. Garamus, M.V. Korobov, M.V. Avdeev, L.A. Bulavin. On a specific state of $\mathrm{C}_{60}$ fullerene in N-methyl-2-pyrrolidone solution: Mass spectrometric study. Appl. Surf. Sci. 481, 1566 (2019).

59. O.B. Karpenko, S.V. Snegir, O.A. Kyzyma et al. Features of ion formation of fullerene $\mathrm{C}_{60}$ in mass spectrometry with laser desorption/ionization. Nanosyst. Nanomater. Nanotekhnol. 10, 763 (2012) (in Ukrainian).

60. A.A. Kaznacheevskaya, O.A. Kizima, L.A. Bulavin, A.V. Tomchuk, V.M. Garamus, M.V. Avdeev. Reorganization of the cluster state in a $\mathrm{C}_{60} / \mathrm{N}$-methylpyrrolidone/water solution: Comparative characteristics of dynamic light scattering and small-angle neutron scattering data. J. Synch. Investig. 7, 1133 (2013).

61. V.L. Aksenov, M.V. Avdeev, O.A. Kyzyma, L. Rosta, M.V. Korobov. Effect of the age of the $\mathrm{C}_{60} / \mathrm{N}$-methyl2-pyrrolidone solution on the structure of clusters in the $\mathrm{C}_{60} / \mathrm{N}$-methyl-2-pyrrolidone/water system according to the small-angle neutron scattering data. Cryst. Rep. 52, 479 (2007).

62. O.A. Kyzyma, M.V. Korobov, M.V. Avdeev, V.M. Garamus, S.V. Snegir, V.I. Petrenko, V.L. Aksenov, L.A. Bulavin. Aggregate development in $\mathrm{C}_{60} / \mathrm{N}$-metyl-2-pyrrolidone solution and its mixture with water as revealed by extraction and mass spectroscopy. Chem. Phys. Lett. 493, 103 (2010).

63. O.A. Kyzyma, M.V. Avdeev, V.L. Aksenov, L.A. Bulavin, S.V. Snegir. Reorganization of fullerene clusters in the sys- 
tem $\mathrm{C}_{60} / \mathrm{N}$-metyl-2-pyrrolidone/water. J. Synch. Investig. 12, 11 (2008).

64. T.V. Tropin, M.V. Avdeev, O.A. Kyzyma, R.A. Yeremin N. Jargalan, M.V. Korobov, V.L. Aksenov. Towards description of kinetics of dissolution and cluster growth in $\mathrm{C}_{60}$ /NMP solutions. Phys. Status Solidi $B$ 248, 2728 (2011).

65. V.L. Aksenov, T.V. Tropin, O.A. Kyzyma, M.V. Avdeev, M.V. Korobov, L. Rosta. Formation of $\mathrm{C}_{60}$ fullerene clusters in nitrogen-containing solvents. Phys. Solid State $\mathbf{5 2}$ 1059 (2010)

66. T.V. Tropin, V.L. Aksenov. Theoretical study of the effect of decrease of cluster sizes on dilution of a solution with water. J. Exper. Theor. Phys. 128, 274 (2019).

67. O.A. Kyzyma, L.A. Bulavin, V.L. Aksenov et al. Aggregation in $\mathrm{C}_{60} / \mathrm{NMP}, \mathrm{C}_{60} / \mathrm{NMP} /$ water and $\mathrm{C}_{60} / \mathrm{NMP} /$ toluene mixtures. Fulleren. Nanotub. Carbon Nanostruct. 16, 610 (2008).

68. J.A. Brant, J. Labille, J.-Y. Bottero, N.R. Wiesner. Characterizing the impact of preparation method on fullerene cluster structure and chemistry. Langmuir 22, 3878 (2006).

69. J. Brant, H. Lecoanet, M.R. Wiesner. Aggregation and deposition characteristics of fullerene nanoparticles in aqueous systems. J. Nanopart. Res. 7, 545 (2007).

70. S.B. Lovern, J.R. Strickler, R. Klaper. Behavioral and physiological changes in Daphnia magna when exposed to nanoparticle suspensions (titanium dioxide, nano- $\mathrm{C}_{60}$, and $\mathrm{C}_{60} \mathrm{HxC}_{70} \mathrm{Hx}$ ). Environ. Sci. Technol. 41, 4465 (2007)

71. C.M. Sayes et al. Nano-C 60 cytotoxicity is due to lipid peroxidation. Biomaterials 26, 7587 (2005)

72. S. Matsuda et al. Genotoxicity of colloidal fullerene $\mathrm{C}_{60}$. Environ. Sci. Technol. 45, 4133 (2011).

73. S. Deguchi, R.Z. Algarova, K. Tsujii. Stable dispersions of fullerenes, $\mathrm{C}_{60}$ and $\mathrm{C}_{70}$, in water. Preparation and characterization. Langmuir 17, 6013 (2001).

74. D.Y. Lyon, L.K. Adams, J.C. Falkner and P.J.J. Alvarez. Antibacterial activity of fullerene water suspensions: Effects of preparation method and particle size. Environ. Sci. Technol. 40, 4360 (2006).

75. I.D. Fortner, D.Y. Lyon, C.M. Sayes, A.M. Boyd J.C. Falkner, E.M. Hotze, L.B. Alemany, Y.I. Tao, W. Guo, K.D. Ausman, V.L. Colvin, J.B. Hughes. $\mathrm{C}_{60}$ in water: Nanocrystal formation and microbial response. Environ. Sci. Technol. 39, 4307 (2005).

76. W.A. Scrivens, J.M. Tour, K.E. Creek, L. Pirisi. Synthesis of $14 \mathrm{C}$-labeled $\mathrm{C}_{60}$, its suspension in water, and its uptake by human keratinocytes. J. Am. Chem. Soc. 116, 4517 (1994).

77. O.A. Kyzyma, M.O. Kuzmenko, L.A. Bulavin, V.I. Petrenko, I.V. Mikheev, M.A. Zabolotnyi, M. Kubovcikova, P. Kopcansky, M.V. Korobov, M.V. Avdeev, V.L. Aksenov. Impact of physiological medium on aggregation state of $\mathrm{C}_{60}$ and $\mathrm{C}_{70}$. J. Synch. Investig. 11, 3 (2016).

78. G.L. Baker, A. Gupta, M.L. Clark, B.R. Valenzuela, L.M. Staska, S.J. Harbo, J.T. Pierce, J.A. Dill. Inhalation toxicity and lung toxicokinetics of $\mathrm{C}_{60}$ fullerene nanoparticles and microparticles. Toxicol. Sci. 101, 122 (2008)
79. J. Ferin, G. Oberdorster, D.P. Penney. Pulmonary retention of ultrafine and fine particles in rats. Am. J. Respir. Cell Mol. Biol. 6, 535 (1992).

80. O.A. Kyzyma, M.V. Avdeev, O.I. Bolshakova, P. Melentev, S.V. Sarantseva, O.I. Ivankov, M.V. Korobov, I.V. Mikheev, T.V. Tropin, M. Kubovcikova, P. Kopcansky, V.F. Korolovych, V.L. Aksenov, L.A. Bulavin. State of aggregation and toxicity of aqueous fullerene solutions. Appl. Surf. Sci. 483, 69 (2019).

81. E.A. Kyzyma, A.A. Tomchuk, L.A. Bulavin, V.I. Petrenko, L. Almasy, M.V. Korobov, D.S. Volkov, I.V. Mikheev, I.V. Koshlan, N.A. Koshlan, P. Blaha, M.V. Avdeev, V.L. Aksenov. Structure and toxicity of aqueous fullerene $\mathrm{C}_{60}$ solutions. J. Synch. Investig. 9, 5 (2015).

82. S. Deguchi, S. Mukai, M. Tsudome, K. Horikoshi. Facile generation of fullerene nanoparticles by hand-grinding. Adv. Mater. 18, 729 (2006).

83. S. Yang, X. Mulet, T. Gengenbach et al. Limitations with solvent exchange methods for synthesis of colloidal fullerenes. Colloid. Surf. A 514, 21 (2017)

84. S. Andreev, D. Purgina, E. Bashkatova, A. Garshev, A. Maerle, I. Andreev, N. Osipova, N. Shershakova, M. Khaitov. Study of fullerene aqueous dispersion prepared by novel dialysis method: Simple way to fullerene aqueous solution. Fulleren. Nanotub. Carbon Nanostruct. 23, 792 (2015).

85. R. Klimova, S. Andreev, E. Momotyuk, N. Demidova, N. Fedorova, Y. Chernoryzh, K. Yurlov, E. Turetskiy, E. Baraboshkina, N. Shershakova, R. Simonov, A. Kushch, M. Khaitov, A. Gintsburg. Aqueous fullerene $\mathrm{C}_{60}$ solution suppresses herpes simplex virus and cytomegalovirus infections. Fulleren. Nanotub. Carbon Nanostruct. 28, 487 (2020).

86. N. Shershakova, E. Baraboshkina, S. Andreev, D. Purgina, I. Struchkova, O. Kamyshnikov, A. Nikonova, M. Khaitov. Anti-inflammatory effect of fullerene $\mathrm{C}_{60}$ in a mice model of atopic dermatitis. J. Nanobiotechnol. 14, 8 (2016).

Received 30.03.20.

Translated from Ukrainian by O.I. Voitenko

\section{О.А. Кизима}

\section{РІДИННІ СИСТЕМИ}

3 ФУЛЕРЕНАМИ В ОРГАНІЧНИХ

РОЗЧИННИКАХ ТА ВОДНИХ СЕРЕДОВИЩАХ

$\mathrm{P}$ е $з$ ю м е

Завдяки унікальним властивостям нановуглецевих матеріалів, зокрема фулеренів, спектр їх використання в різних напрямках промисловості, включаючи хімічну, енергетичну, фармацевтичну, за останні роки розширюється лавиноподібно, захоплюючи нові галузі, що зумовлює появу нових наукових задач. Так, досі ведеться пошук нових методик отримання біосумісних рідинних систем фулеренів з монодисперсними агрегатами малого розміру. В роботі розглянуто властивості рідинних систем фулеренів у сумішах органічних розчинників, на основі яких були розроблені нові методики синтезу водних рідинних систем з фулеренами. 